\title{
Effects of two organotin(IV)(sulfonatophenyl)porphinates on MAPKs and on the growth of A375 human melanoma cells
}

\author{
MARIA ASSUNTA COSTA ${ }^{1}$, LETIZIA GULINO ${ }^{1}$, LORENZO PELLERITO², TIZIANA FIORE ${ }^{2}$, \\ CLAUDIA PELLERITO $^{2}$ and GIOVANNA BARBIERI ${ }^{1}$ \\ ${ }^{1}$ Istituto di Biomedicina e Immunolgia Molecolare ‘Alberto Monroy', Consiglio Nazionale delle Ricerche (CNR), \\ Via Ugo La Malfa 153, 90146 Palermo, ${ }^{2}$ Dipartimento di Chimica Inorganica e Analitica, Università degli \\ Studi di Palermo, Viale delle Scienze, 90128 Palermo, Italy
}

Received April 4, 2008; Accepted July 17, 2008

DOI: 10.3892/or_00000261

\begin{abstract}
Previously we showed apoptotic induction in A375 human melanoma cells using two complexes of the mesotetra(4-sulfonatophenyl)porphinate (TPPS), $\left(\mathrm{Bu}_{2} \mathrm{Sn}\right)_{2}$ TPPS and $\left(\mathrm{Bu}_{3} \mathrm{Sn}\right)_{4}$ TPPS. To understand how these compounds activate apoptosis in melanoma cells we studied MAPKs and the $\left(\mathrm{Bu}_{2} \mathrm{Sn}\right)_{2}$ TPPS and $\left(\mathrm{Bu}_{3} \mathrm{Sn}\right)_{4}$ TPPS cellular uptake. Western blotting experiments showed activated protein kinases ERK $1 / 2$, JNK and p38 in $10 \mu \mathrm{M}\left(\mathrm{Bu}_{2} \mathrm{Sn}\right)_{2}$ TPPS- and $1 \mu \mathrm{M}\left(\mathrm{Bu}_{3} \mathrm{Sn}\right)_{4} \mathrm{TPPS}$-treated melanoma cells, which suggests that the three MAP kinases are involved in the apoptotic death of A375-treated cells. By taking advantage of the porphyrin fluorescence, we found a fast concentration of $\left(\mathrm{Bu}_{2} \mathrm{Sn}\right)_{2} \mathrm{TPPS}$ and $\left(\mathrm{Bu}_{3} \mathrm{Sn}\right)_{4}$ TPPS in the nucleus and in the nucleoli compared to TPPS. A significantly reduced growth of A375 human melanoma cells was also observed after only $48 \mathrm{~h}$ treatment by using $500 \mathrm{nM}$ of $\left(\mathrm{Bu}_{2} \mathrm{Sn}\right)_{2}$ TPPS or $80 \mathrm{nM}$ of $\left(\mathrm{Bu}_{3} \mathrm{Sn}\right)_{4}$ TPPS. A strong slowdown of cell growth and loss of cell-cell interactions were visible by in vitro wound repair assay.
\end{abstract}

\section{Introduction}

Malignant melanoma is the most aggressive and lethal type of cutaneous cancer. The incidence of melanoma is rising steadily in western populations, with the number of cases having doubled in the past 20 years. If melanoma is diagnosed early it can be cured by surgical resection, but once it has progressed to the metastatic stage it is largely refractory to

Correspondence to: Dr Maria Assunta Costa, Istituto di Biomedicina e Immunologia Molecolare 'Alberto Monroy', Consiglio Nazionale delle Ricerche (CNR), Via Ugo La Malfa 153, 90146 Palermo, Italy

E-mail: costama@ibim.cnr.it

Key words: A375 melamoma cells, meso-tetra(4-sulfonatophenyl) porphinate, MAPKs, FAK, cell growth existing therapies and has a very poor prognosis $(1,2)$. Melanoma cells have low levels of spontaneous apoptosis in vivo compared with other tumor cell types, and are relatively resistant to drug-induced apoptosis in vitro. Most chemotherapeutic drugs function by inducing apoptosis in malignant cells. Thus, resistance to apoptosis is likely to underlie drug resistance in melanoma, and this notable resistance to chemotherapy, radiotherapy and immunotherapy is a significant barrier to successful treatment of melanoma (1). Therefore, studies in the field of melanoma are required to identify new molecular targets for effective anti-cancer agents suitable for overcoming melanoma drug resistance. Further knowledge of the intrinsic survival features acquired by the melanoma cells, promoting proliferation, invasion and blocking of the apoptotic cell death pathways, is being exploited to provide targeted drugs and new therapeutic approaches.

In this context, we regarded a class of porphyrin derivatives as potential anti-tumor drugs for their cytotoxicity and for the property of the porphyrins themselves to be accumulated in large amounts and retained for prolonged periods of time by the malignant lesions as noteworthy (3-5). We showed that two complexes of the meso-tetra(4-sulfonatophenyl) porphinate (TPPS), $\left(\mathrm{Bu}_{2} \mathrm{Sn}\right)_{2}$ TPPS and $\left(\mathrm{Bu}_{3} \mathrm{Sn}\right)_{4} \mathrm{TPPS}$, induce the activation of extrinsic and intrinsic apoptotic pathways in melanoma cells (6). Based on these results, we aimed to identify the molecular targets of the compounds involved in apoptotic death of melanoma cells. In particular, we investigated the MAPK family and FAK.

MAPKs play key roles in oncogenic and tumor-suppressing activities. Prior to the discovery of the JNK and p38 kinases, the MAPK family included the extracellular signal-regulated kinases ERK1 and ERK2. ERKs were known to become active in response to mitogenic signals and proliferative cytokines (7), while initially JNKs and later p38s were considered to be stress-activated protein kinases (SAPKs) $(8,9)$. It was considered that ERKs, p38s and JNKs have distinct physiological properties, and it was generally accepted that ERKs are pro-oncogenic, while p38s and JNKs inhibit proliferation. Investigations have challenged these ideas, as several MAP kinases may phosphorylate the same substrates and affect each other via cross-talk reactions and feedback mechanisms 
(10). In human melanoma it has been demonstrated that ERK is constitutively active (11). ERK activity is important for imposing the cancerous phenotype characterized by cell growth, invasion and metastasis. ERK overexpression or constitutive activation of this pathway has been shown to play an important role in the pathogenesis and progression of breast and other cancer types, making the components of this signaling cascade potentially important as therapeutic targets (12).

FAK, a cytoplasmic protein kinase that co-localizes with integrins at structures called focal adhesions, heavily enriched in structural and signaling molecules (13), promotes cell survival and migration when it is activated $(14,15)$. FAK is expressed at higher levels in invasive tumors than in benign pre-neoplastic tumors (16), and in human malignant melanoma it is constitutively active and essential for maintaining adhesiveness in melanoma cells (17).

Concomitant to these studies, we identified concentrations of $\left(\mathrm{Bu}_{2} \mathrm{Sn}\right)_{2}$ TPPS and $\left(\mathrm{Bu}_{3} \mathrm{Sn}\right)_{4}$ TPPS which were less toxic but sufficient to affect A375 melanoma cell growth.

Invasion and metastasis of tumors are highly complex and multistep processes. Tumor cells modulate their ability to adhere, degrade the surrounding extracellular matrix (ECM), migrate and proliferate (18). Cell movement is controlled by various factors, including growth and motility factors, cytokines, matrix proteins and cell-adhesion molecules (19). Knowledge of this process has increased in recent times and the identification of an even larger number of the involved molecules is necessary to provide additional targets for therapies.

In this study, we show that the three MAPKs, ERK 1/2, JNK and p38, are involved in A375 melanoma cell apoptosis induced by $10 \mu \mathrm{M}\left(\mathrm{Bu}_{2} \mathrm{Sn}\right)_{2}$ TPPS or $1 \mu \mathrm{M}\left(\mathrm{Bu}_{3} \mathrm{Sn}\right)_{4}$ TPPS, and that FAK does not activate this pathway. We show a rapid cell uptake of the two compounds, including the nucleus and nucleoli, as well as a considerable slowdown of cell growth by using lower concentrations of $\left(\mathrm{Bu}_{2} \mathrm{Sn}\right)_{2}$ TPPS and $\left(\mathrm{Bu}_{3} \mathrm{Sn}\right)_{4}$ TPPS at 500 and $80 \mathrm{nM}$, respectively.

\section{Materials and methods}

Cell cultures. The A375 human melanoma cell line (ATCCCRL-1619) (20) was provided by Professor Catherine Alcaide-Loridan and Dr Reem Al-Daccak. The cells were cultured in RPMI medium supplemented with $10 \%$ heatinactivated fetal calf serum (FCS) and $1 \%$ penicillinstreptomycin in $5 \% \mathrm{CO}_{2}$ at $37^{\circ} \mathrm{C}$.

Compounds and antibodies. $\left(\mathrm{Bu}_{2} \mathrm{Sn}\right)_{2}$ TPPS, and $\left(\mathrm{Bu}_{3} \mathrm{Sn}\right)_{4}$ TPPS were prepared according to previously reported procedures (3) and dissolved as previously reported (6).

Antibodies that recognize the phosphorylated form of ERK 1/2, JNK and p38 were purchased from Cell Signaling Technology (Beverly, MA, USA). Anti-FAK (clone 77) and anti-pFAK (pTyr-397 motif clone 14) monoclonal antibodies were purchased from BD Transduction Laboratories (Lexington, KY). Anti- 3 -actin is a mouse monoclonal antibody purchased from Sigma (St. Louis, MO). HRP-conjugated anti-rabbit and anti-mouse antibodies were purchased from GE Healthcare, Biosciences (Buckinghamshire, UK).

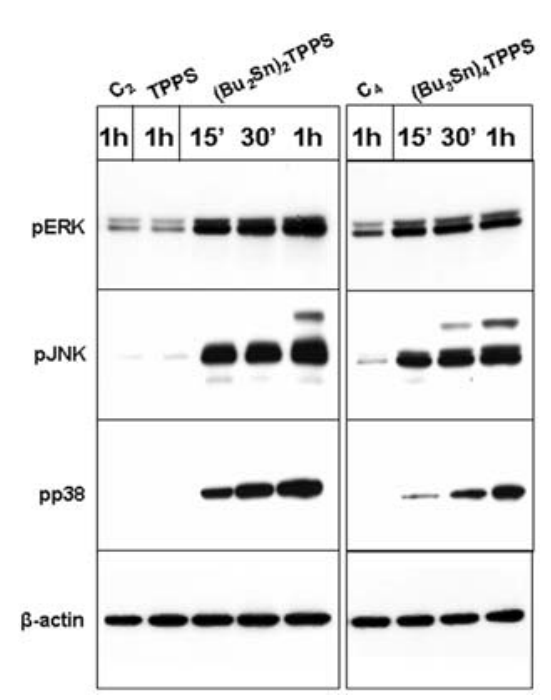

Figure 1. Effects of $\left(\mathrm{Bu}_{2} \mathrm{Sn}\right)_{2}$ TPPS and $\left(\mathrm{Bu}_{3} \mathrm{Sn}\right)_{4}$ TPPS on MAPK phosphorylation in A375 melanoma cells. Cells were grown in 100-mm culture dishes $\left(3 \times 10^{6}\right.$ cells/dish) for $24 \mathrm{~h}$ and then treated with $10 \mu \mathrm{M}\left(\mathrm{Bu}_{2} \mathrm{Sn}\right)_{2}$ TPPS or $1 \mu \mathrm{M}\left(\mathrm{Bu}_{3} \mathrm{Sn}\right)_{4}$ TPPS for $15 \mathrm{~min}, 30 \mathrm{~min}$ and $1 \mathrm{~h}$. Equal amounts of protein $(50 \mu \mathrm{g})$ from each sample were subjected to $10 \%$ SDS-PAGE and analyzed by immunoblotting using anti-phospho-ERK 1/2, -JNK and -p38 at the dilution described in Materials and methods. $\mathrm{C}_{2}$, untreated cells as the control for $\left(\mathrm{Bu}_{2} \mathrm{Sn}\right)_{2}$ TPPS and $\mathrm{C}_{4}, 0.1 \%$ DMSO-treated cells as the control for $\left(\mathrm{Bu}_{3} \mathrm{Sn}\right)_{4} \mathrm{TPPS}$. The reaction with $\beta$-actin antibody confirms the equal protein loading. The results are representative of three independent experiments.

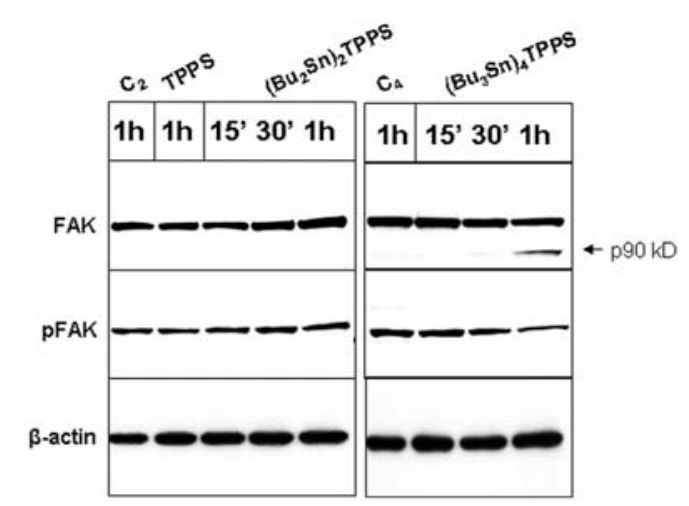

Figure 2. FAK in $\left(\mathrm{Bu}_{2} \mathrm{Sn}\right)_{2}$ TPPS- or $\left(\mathrm{Bu}_{3} \mathrm{Sn}\right)_{4}$ TPPS-treated A375 cells. Cells were grown and treated as described in Fig. 1. Protein $(50 \mu \mathrm{g})$ per lane was separated by $10 \%$ SDS-PAGE and analyzed by immunoblotting using antiFAK and anti-phospho-FAK at the dilution described in Materials and methods. $\mathrm{C}_{2}$ and $\mathrm{C}_{4}$ are the controls of $\left(\mathrm{Bu}_{2} \mathrm{Sn}\right)_{2}$ TPPS and $\left(\mathrm{Bu}_{3} \mathrm{Sn}\right)_{4}$ TPPS, respectively, as described in Fig. 1. Equal protein loading was confirmed by reaction with $B$-actin antibody. The results are representative of three independent experiments.

Western blotting. Cell lysates, protein determination, and Western blotting were performed as previously described (6). The membranes were incubated overnight with anti-phosphoERK 1/2, -JNK and -p38 (1:1000), and anti-FAK and antiphospho-FAK (1:500). After several washes, the membranes were incubated with either HRP-conjugated anti-rabbit or anti-mouse antibodies (diluted at 1:5000) for $1 \mathrm{~h}$. Bound antibodies were detected using an enhanced chemiluminescence kit (SuperSignal West Pico Chemiluminescent Substrate, Pierce). 

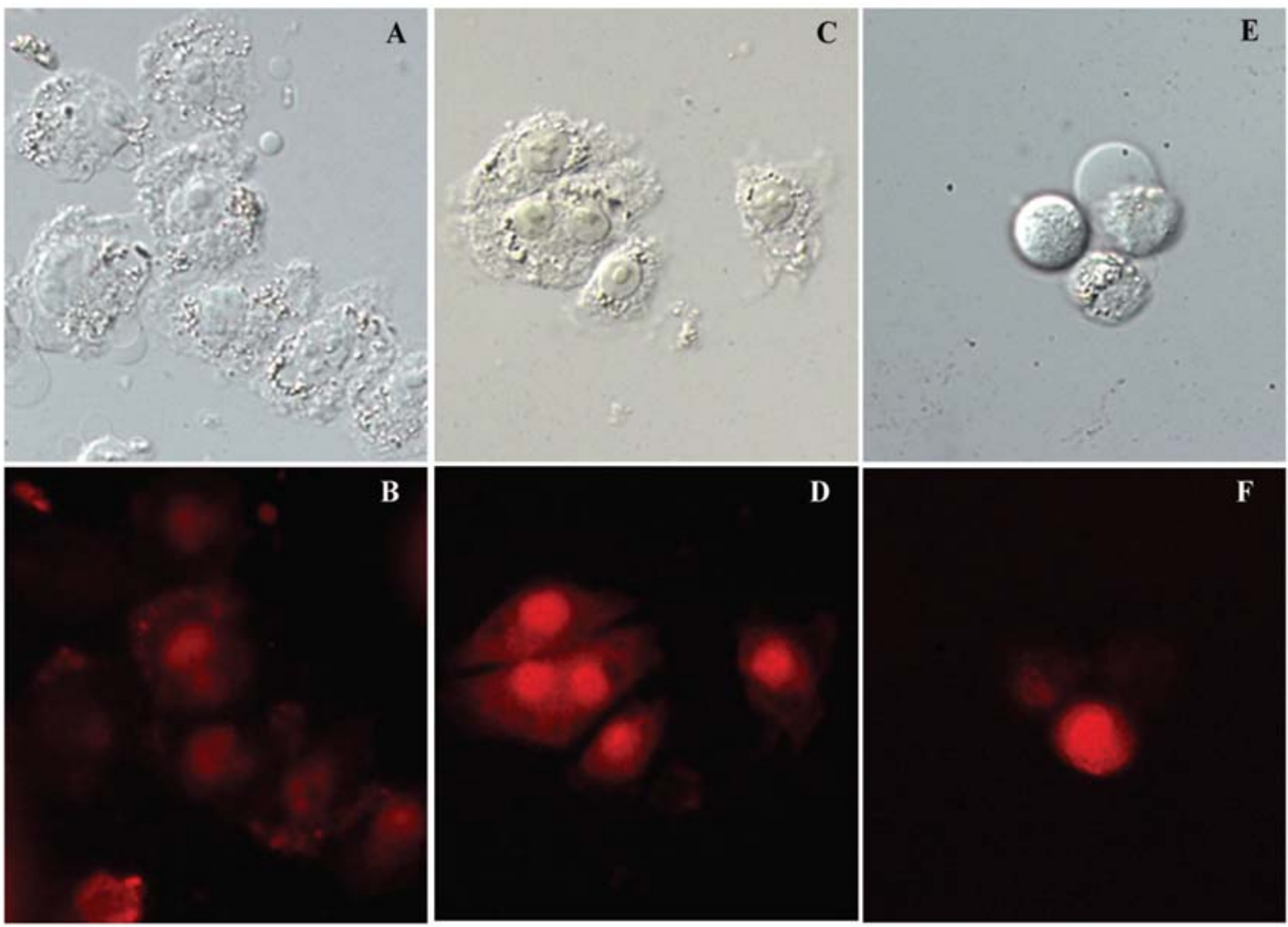

Figure 3. Localization of TPPS, $\left(\mathrm{Bu}_{2} \mathrm{Sn}\right)_{2}$ TPPS and $\left(\mathrm{Bu}_{3} \mathrm{Sn}\right)_{4}$ TPPS in A375 cells. Normaski (A, C and E) and fluorescence (B, D and F) images of living A375 cells treated with TPPS (A and $\mathrm{B}),\left(\mathrm{Bu}_{3} \mathrm{Sn}\right)_{4} \mathrm{TPPS}(\mathrm{C}$ and $\mathrm{D})$ and $\left(\mathrm{Bu}_{2} \mathrm{Sn}\right)_{2} \mathrm{TPPS}(\mathrm{E}$ and $\mathrm{F})$. Cells were grown, treated and processed as described in Materials and methods.

Fluorescence microscope digital imaging. Cells $\left(4 \times 10^{4}\right.$ cells/well in $400 \mu 1$ growth medium) were plated on an 8-well Lab-Tek II chamber slide, cultured for $24 \mathrm{~h}$ and then treated with $80 \mu \mathrm{g} / \mathrm{ml}$ of TPPS, or $\left(\mathrm{Bu}_{2} \mathrm{Sn}\right)_{2} \mathrm{TPPS}$, or $\left(\mathrm{Bu}_{3} \mathrm{Sn}\right)_{4} \mathrm{TPPS}$ for $1 \mathrm{~h}$. We removed the medium from every chamber and washed twice with $400 \mu \mathrm{l}$ of medium without serum and twice more with $200 \mu 1$. Then we removed the medium leaving $50 \mu \mathrm{l}$ and put coverslips on the slides. Fluorescence images (excitation, $550 \mathrm{~nm}$ and emission, $580 \mathrm{~nm}$ ) were obtained using a Zeiss Axioskop 2 Plus microscope, equipped for epifluorescence and recorded by a digital camera system.

Cell growth assay. A375 cells $\left(1.5 \times 10^{5}\right.$ cells/well $)$ were grown in 12-well plates for $24 \mathrm{~h}$ and then treated with $500 \mathrm{nM}$ $\left(\mathrm{Bu}_{2} \mathrm{Sn}\right)_{2}$ TPPS or with $80 \mathrm{nM}\left(\mathrm{Bu}_{3} \mathrm{Sn}\right)_{4}$ TPPS in complete medium for 24,48 , or $72 \mathrm{~h}$. The treatment was renewed daily. At the end of drug challenge, cells were recovered and counted using trypan blue exclusion test. We used trypsin $0.05 \%$ and EDTA $0.02 \%$ in PBS to harvest cells.

In vitro wound repair assay. Cells $\left(3 \times 10^{6}\right.$ cells/dish) were grown in 100-mm culture dishes for $24 \mathrm{~h}$. Cell dishes were scraped with a sterile micropipette tip, and the culture medium was replaced with fresh medium to which $500 \mathrm{nM}\left(\mathrm{Bu}_{2} \mathrm{Sn}\right)_{2}$ TPPS or $80 \mathrm{nM}\left(\mathrm{Bu}_{3} \mathrm{Sn}\right)_{4}$ TPPS was added. The treatment and culture medium were renewed daily. Photographs were taken at $0,24,48$, and $72 \mathrm{~h}$ after treatment. Pictures were taken by inverted microscope with $\mathrm{X} 4$ objective.

\section{Results}

Phosphorylation of ERK 1/2, JNK and p38 MAPKs in response to $\left(B u_{2} S n\right)_{2}$ TPPS and $\left(B u_{3} S n\right)_{4}$ TPPS does not require $F A K$ involvement. In order to determine whether MAPKs are involved in A375 human melanoma cell apoptosis induced by $10 \mu \mathrm{M}\left(\mathrm{Bu}_{2} \mathrm{Sn}\right)_{2} \mathrm{TPPS}$ or $1 \mu \mathrm{M}\left(\mathrm{Bu}_{3} \mathrm{Sn}\right)_{4} \mathrm{TPPS}(6)$, we examined the three members of the MAPK family, ERK1/2, JNK and p38, by using Western blotting with antibodies that recognize the activated phosphorylated forms of the three kinases. We analyzed initial treatment and found the activation of the three kinases to be at $15 \mathrm{~min}$ for the two compounds (Fig. 1). FAK was analyzed concomitantly. We did not find any difference in FAK activity between the $\left(\mathrm{Bu}_{2} \mathrm{Sn}\right)_{2-}$ TPPS-treated cells and the untreated cells by Western blotting. We found FAK dephosphorylation and cleavage $(\mathrm{p} 90 \mathrm{kD})$ in $\left(\mathrm{Bu}_{3} \mathrm{Sn}\right)_{4}$ TPPS-treated A375 cells, but only after $1 \mathrm{~h}$ of treatment (Fig. 2) when the caspases had already been activated (6). Accordingly, FAK is not involved in activation of the apoptotic pathway, but is one of the final targets of the pathway (21).

Cell localization of $\left(B u_{2} S n\right)_{2}$ TPPS and $\left(B u_{3} S n\right)_{4} T P P S$. The cell localization of $\left(\mathrm{Bu}_{2} \mathrm{Sn}\right)_{2}$ TPPS and $\left(\mathrm{Bu}_{3} \mathrm{Sn}\right)_{4}$ TPPS in A375 human melanoma cells was characterized by using a conventional fluorescence microscope (Fig. 3). By exploiting porphyrin fluorescence, living cells were observed after $1 \mathrm{~h}$ of incubation with $80 \mu \mathrm{g} / \mathrm{ml}$ of TPPS, or $\left(\mathrm{Bu}_{2} \mathrm{Sn}\right)_{2} \mathrm{TPPS}$, or 


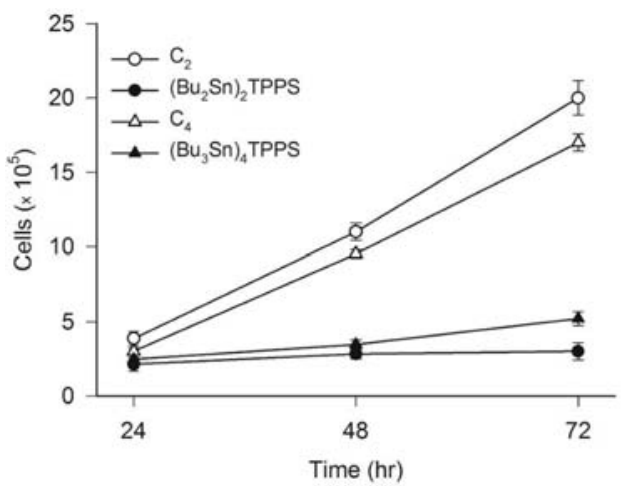

Figure 4. Effects of $\left(\mathrm{Bu}_{2} \mathrm{Sn}\right)_{2} \mathrm{TPPS}$ and $\left(\mathrm{Bu} \mathrm{Sn}_{3}\right)_{4} \mathrm{TPPS}$ on $\mathrm{A} 375$ melanoma cell growth. Cells, grown in 12-well plates $24 \mathrm{~h}$ before, were challenged with $500 \mathrm{nM}\left(\mathrm{Bu}_{2} \mathrm{Sn}\right)_{2}$ TPPS or with $80 \mathrm{nM}\left(\mathrm{Bu}_{3} \mathrm{Sn}\right)_{4} \mathrm{TPPS}$ for 24,48 , or $72 \mathrm{~h}$. The incubation medium containing the drug was changed daily. $\mathrm{C}_{2}$, $\left(\mathrm{Bu}_{2} \mathrm{Sn}\right)_{2}$ TPPS control for untreated cells and $\mathrm{C}_{4},\left(\mathrm{Bu}_{3} \mathrm{Sn}\right)_{4}$ TPPS control for cells treated with $0.1 \%$ DMSO. The cell number was evaluated by trypan blue exclusion test at the end of treatment. Error bars represent the standard deviation of three separate experiments.
$\left(\mathrm{Bu}_{3} \mathrm{Sn}\right)_{4}$ TPPS. As shown in Fig. 3, in $\left(\mathrm{Bu}_{3} \mathrm{Sn}\right)_{4}$ TPPS-treated A375 cells a minor concentration of the compound remains in the cytoplasm while the majority of the concentration enters the nucleus and concentrates in the nucleoli compared with the TPPS-treated cells. In $\left(\mathrm{Bu}_{2} \mathrm{Sn}\right)_{2}$ TPPS-treated cells this distribution is poorly evaluated since cells get detached and round immediately after treatment.

Cell growth kinetics. Fig. 4 shows the effects of $\left(\mathrm{Bu}_{2} \mathrm{Sn}\right)_{2}$ TPPS or $\left(\mathrm{Bu}_{3} \mathrm{Sn}\right)_{4}$ TPPS on the proliferation of A375 cells, calculated by variation of the number of cells recovered from multiwell plates after 24,48 and $72 \mathrm{~h}$ treatment. We used lower concentrations than those inducing apoptosis, specifically $500 \mathrm{nM}$ of $\left(\mathrm{Bu}_{2} \mathrm{Sn}\right)_{2}$ TPPS and $80 \mathrm{nM}$ of $(\mathrm{Bu} 3 \mathrm{Sn})_{4}$ TPPS. No significant increase in cell number was observed over these treatment periods for the two compounds, as determined by the cell count harvested from the plates. Moreover, after $72 \mathrm{~h}$ and without any more treatment the $\left(\mathrm{Bu}_{3} \mathrm{Sn}\right)_{4}$ TPPS-treated cells remained alive and did not

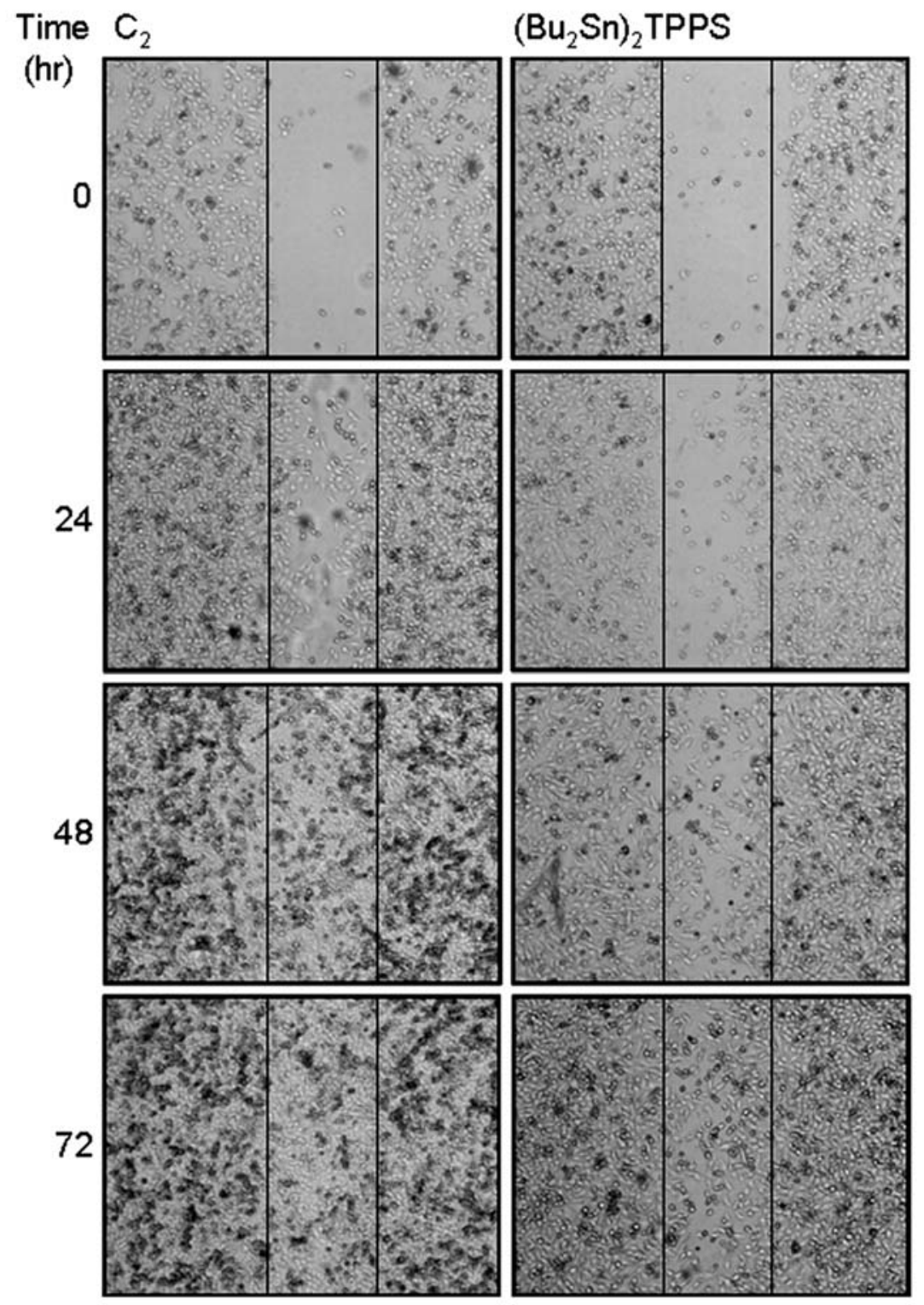

Figure 5. Wound repair assay in A375 cells treated with $500 \mathrm{nM}$ of $\left(\mathrm{Bu}_{2} \mathrm{Sn}\right)_{2}$ TPPS. Cells were grown and treated as described in Materials and methods, an artificial wound was introduced with a micropipette tip into cultures and wound closure was followed for 3 days. $\mathrm{C}_{2}$, $\left(\mathrm{Bu} \mathrm{u}_{2} \mathrm{Sn}\right)_{2} \mathrm{TPPS}$ control for untreated cells. Pictures were taken every $24 \mathrm{~h}$ with X4 objective. 


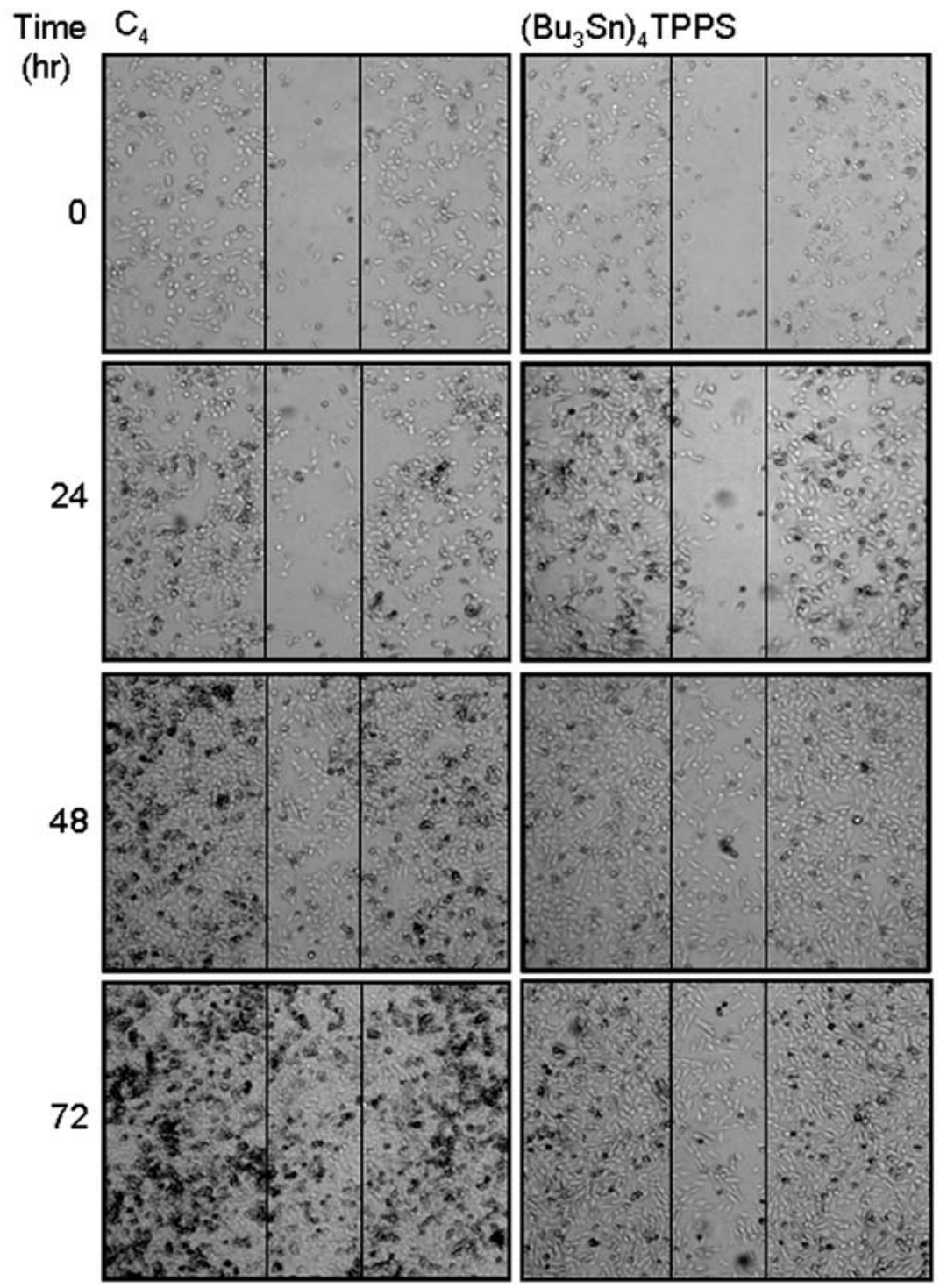

Figure 6. Wound repair assay in A375 cells treated with $80 \mathrm{nM}$ of $\left(\mathrm{Bu}_{3} \mathrm{Sn}\right)_{4} \mathrm{TPPS}$. Assay was performed as described in Fig. 5. $\mathrm{C}_{4},\left(\mathrm{Bu} \mathrm{S}_{3} \mathrm{Sn}\right)_{4} \mathrm{TPPS}$ control for cells treated with $0.1 \%$ DMSO.

proliferate for another 3 days. In contrast, the $\left(\mathrm{Bu}_{2} \mathrm{Sn}\right)_{2} \mathrm{TPPS}$ treated cells detached and died after this time (data not shown).

Scratch wound healing assay. The effects of $\left(\mathrm{Bu}_{2} \mathrm{Sn}\right)_{2} \mathrm{TPPS}$ $500 \mathrm{nM}$ and $\left(\mathrm{Bu}_{3} \mathrm{Sn}\right)_{4} \mathrm{TPPS} 80 \mathrm{nM}$ on A375 cell proliferation were investigated by in vitro wound repair assay. After scraping, the untreated cells invaded the denuded area more quickly than the treated cells, as shown in Figs. 5 and 6. A cell morphological transformation can already be observed in the treated cells at $24 \mathrm{~h}$, which becomes greatly evident at $72 \mathrm{~h}$ of treatment. The cells appear to lose cell-cell interactions and to become spindle-shaped, as shown in Fig. 7. Specifically the $\left(\mathrm{Bu}_{3} \mathrm{Sn}\right)_{4} \mathrm{TPPS}$-treated cells showed this spindle and elongated shape, as well as a strong adhesiveness to the plate. The $\left(\mathrm{Bu}_{3} \mathrm{Sn}\right)_{4}$ TPPS-treated cells were more resistant to trypsin than the untreated and $\left(\mathrm{Bu}_{2} \mathrm{Sn}\right)_{2}$ TPPS-treated cells. Usually, we detach A375 melanoma cells from plates by trypsin/EDTA solution for $5 \mathrm{~min}$ at room temperature. For the $\left(\mathrm{Bu}_{3} \mathrm{Sn}\right)_{4} \mathrm{TPPS}$-treated cells we had to use longer periods of time and incubation at $37^{\circ} \mathrm{C}$ to detach cells.

\section{Discussion}

Cutaneous melanoma has been one of the fastest-rising malignancies for several decades. In contrast to many other cancer types, melanoma affects a relatively younger population and is notorious for its propensity to metastasize and for its poor response to current therapeutic regimens $(22,23)$. At present, the available therapies contribute little to patient survival. Thus, the identification of molecules involved in the signaling pathways, leading to melanoma drug resistance and progression, provides the opportunity to develop targeted therapies.

Two porphyrin derivatives, $\left(\mathrm{Bu}_{2} \mathrm{Sn}\right)_{2}$ TPPS and $\left(\mathrm{Bu}_{3} \mathrm{Sn}\right)_{4}$ TPPS, proved effective in countering melanoma cell drug resistance in vitro. The two compounds induce apoptosis in A375 human melanoma cells, as we showed previously (6). It was important to understand how these compounds activate apoptosis in melanoma cells. Therefore, we focused our attention on the identification of targets of the $\left(\mathrm{Bu}_{2} \mathrm{Sn}\right)_{2} \mathrm{TPPS}$ and $\left(\mathrm{Bu}_{3} \mathrm{Sn}\right)_{4} \mathrm{TPPS}$ complexes and their cellular uptake. We analyzed MAPKs, and their analysis showed the activation of 


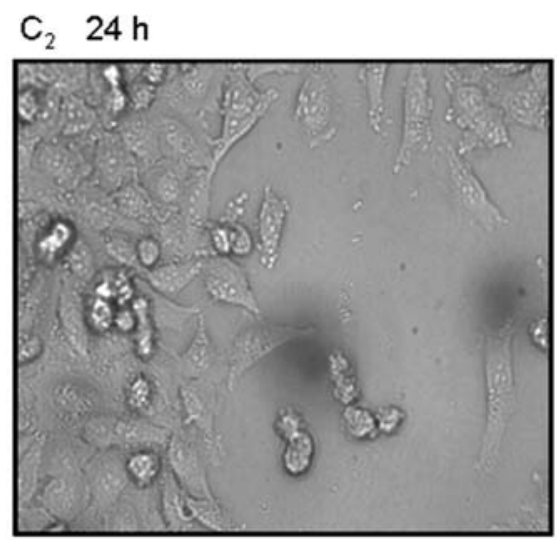

$\left(\mathrm{Bu}_{2} \mathrm{Sn}\right)_{2}$ TPPS $48 \mathrm{~h}$
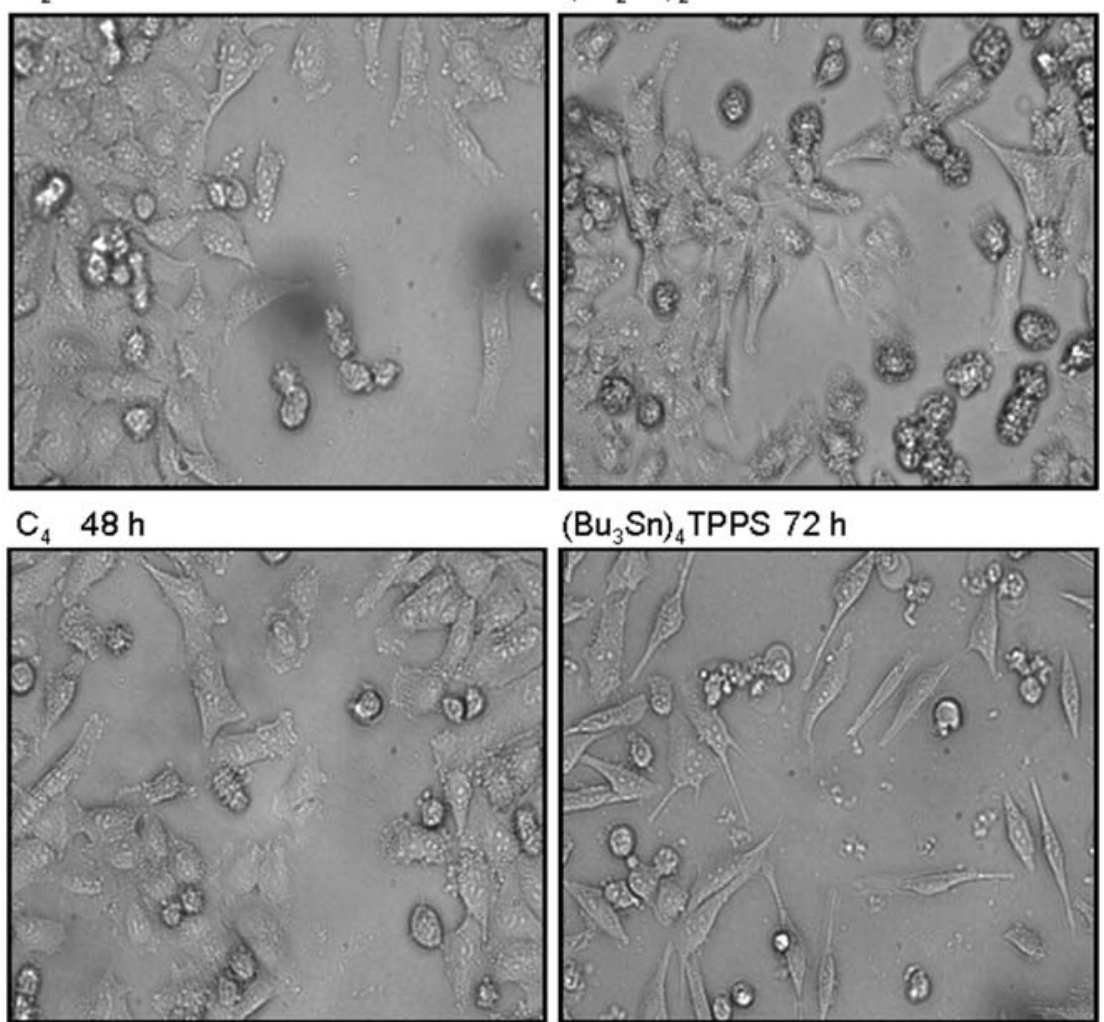

$\left(\mathrm{Bu}_{3} \mathrm{Sn}\right)_{4}$ TPPS $72 \mathrm{~h}$

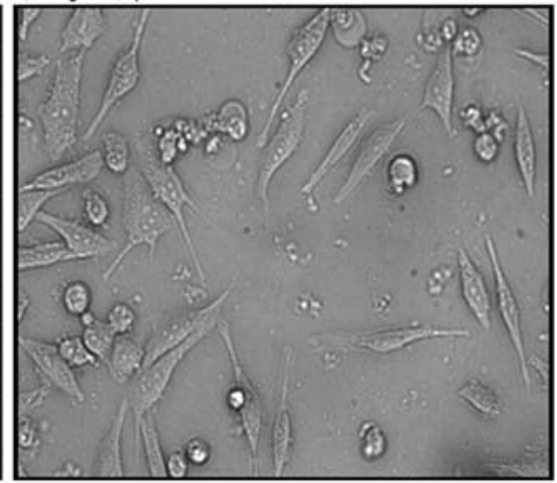

Figure 7. Magnification of some regions in Figs. 5 and 6. Pictures were taken with X20 objective. Different times were chosen in order to highlight better the cell morphology.

the three kinases, ERK 1/2, JNK and p38. These results surprised us initially, because we expected JNK and p38 activation but not a hyperphosphorylation of ERKs. JNK and p38 MAPK are involved in the regulation of apoptosis (24-26), whereas ERK activation results in cell survival and proliferation $(27,28)$. Nevertheless, increasing studies now assign contrasting physiological roles to the same MAPK (10). Therefore we state that the $\left(\mathrm{Bu}_{2} \mathrm{Sn}\right)_{2}$ TPPS and $\left(\mathrm{Bu}_{3} \mathrm{Sn}\right)_{4}$ TPPS complexes induce apoptotic death of A375 human melanoma cells through activation of the three MAPKs. We aimed to investigate what triggers MAPK activation and, since the two compounds contain butyl, our hypothesis was that they would be able to affect certain proteins associated with plasma membrane. Thus, we analyzed FAK that is constitutively activated in melanoma cells and whose activation has also been shown to promote cell survival and migration $(14,15)$. Moreover, FAK expression attenuation induces apoptosis in several human cell lines including melanoma (29), and its dephosphorylation is correlated with apoptosis (30). We did not find any difference in FAK phosphorylation between the $\left(\mathrm{Bu}_{2} \mathrm{Sn}\right)_{2}$ TPPS-treated and untreated cells at different treatment times. We observed FAK dephosphorylation and cleavage only in $\left(\mathrm{Bu}_{3} \mathrm{Sn}\right)_{4}$ TPPStreated A375 cells, but after $1 \mathrm{~h}$ of treatment when the caspases had already been activated (6), which is in agreement with what has been reported (21). Therefore, FAK is not a direct target of these compounds but rather a downstream target of the apoptotic pathway. However, by investigating the $\left(\mathrm{Bu}_{2} \mathrm{Sn}\right)_{2}$ TPPS and $\left(\mathrm{Bu}_{3} \mathrm{Sn}\right)_{4}$ TPPS cellular uptake, we found a rapid concentration of the two compounds within cells. In particular, after only $1 \mathrm{~h}$ of treatment a minor concentration remained in the cytoplasm while the majority of the concentration entered the nucleus and concentrated in the nucleoli compared to the TPPS-treated cells. It is likely that the targets are in the cytoplasm and/or in the nucleus, since the butyl-TPPS derivatives enter the cells quickly.

During these studies, we aimed to identify the lowest concentrations of the two compounds that were less toxic but sufficient to kill the melanoma cells. Interestingly, we found a significantly reduced growth of tumor cells after only $48 \mathrm{~h}$ treatment by using $500 \mathrm{nM}$ of $\left(\mathrm{Bu}_{2} \mathrm{Sn}\right)_{2}$ TPPS or $80 \mathrm{nM}$ of $\left(\mathrm{Bu}_{3} \mathrm{Sn}\right)_{4} \mathrm{TPPS}$, concentrations that were non-toxic even after $72 \mathrm{~h}$ of treatment, at least for the $\left(\mathrm{Bu}_{3} \mathrm{Sn}\right)_{4} \mathrm{TPPS}$ compound. At $24 \mathrm{~h}$ of treatment, cell morphology changed and the cell proliferation slowed down for the two compounds. With time the cells treated with $\left(\mathrm{Bu}_{3} \mathrm{Sn}\right)_{4} \mathrm{TPPS}$ appeared to stretch and lose cell contact. We analyzed MAPKs and FAK in A375 cells treated with these low concentrations, but found no difference in comparison with the untreated cells (data not shown).

These results indicate that investigation of the $\mathrm{Wnt} / \mathrm{B}$ catenin signaling pathway is very important. Many melanomas exhibit constitutively elevated levels of nuclear $\beta$-catenin $(31,32)$. B-catenin plays a key role in several developmental processes $(33,34)$, and the activation of $\mathrm{Wnt} / \mathrm{B}$-catenin signaling pathway has been linked to a metastatic or migratory phenotype (35). It is likely that our compounds affect this pathway and the identification of possible targets are a contribution to the development of newly targeted therapies which will challenge melanoma progression. 
In conclusion, we demonstrated that $\left(\mathrm{Bu}_{2} \mathrm{Sn}\right)_{2} \mathrm{TPPS}$ and $\left(\mathrm{Bu}_{3} \mathrm{Sn}\right)_{4}$ TPPS induce A375 melanoma cell apoptosis by MAPK activation, and that low concentrations of the two compounds substantially slow down the growth of A375 cells in vitro.

\section{Acknowledgements}

We thank Dr F. Zito for her skilful technical assistance in fluorescence microscopy, Professor M.T. Musmeci for generously providing several reagents, Dr D. Giacomazza of the Istituto di BioFisica (IBF), Consiglio Nazionale delle Ricerche, for providing the inverted microscope and special thanks to Dr E. Izzo for critical reading of the manucript..

\section{References}

1. Gray-Schopfer V, Wellbrock C and Marais R: Melanoma biology and new targeted therapy. Nature 445: 851-857, 2007.

2. Cummins DL, Cummins JM, Pantle H, Silverman MA, Leonard AL and Chanmugam A: Cutaneous malignant melanoma. Mayo Clin Proc 81: 500-507, 2006.

3. Pellerito A, Fiore T, Giuliani AM, Maggio F, Pellerito L and Mansueto C: Organometallic complexes with biological molecules: IX. Diorgano-and Triorgano-tin(IV)[meso-tetra(4sulfonatophenyl)porphinate] derivates: solid-state and solutionphase structural aspects and in vivo effects. Appl Organomet Chem 11: 707-719, 1997.

4. Tita SP and Perussi JR: The effect of porphyrins on normal and transformed mouse cell lines in the presence of visible light. Braz J Med Biol Res 34: 1331-1336, 2001.

5. Chwilkowska A, Saczko J, Modrzycka T, Marcinkowska A, Malarska A, Bielewicz J, Patalas D and Banas T: Uptake of photofrin II, a photosensitizer used in photodynamic therapy, by tumour cells in vitro. Acta Biochim Pol 50: 509-513, 2003.

6. Costa MA, Pellerito L, Izzo V, Fiore T, Pellerito C, Melis M, Musmeci MT and Barbieri G: Diorganotin(IV) and triorganotin(IV) complexes of meso-tetra(4-sulfonatophenil)porphine induce apoptosis in A375 human melanoma cells. Cancer Lett 238: 284-294, 2006.

7. Robinson MJ and Cobb MH: Mitogen-activated protein kinase pathways. Curr Opin Cell Biol 9: 180-186, 1997.

8. Kyriakis JM, Banerjee P, Nikolakaki E, Dai T, Rubie EA, Ahmad MF, Avruch J and Woodgett JR: The stress-activated protein kinase subfamily of c-Jun kinases. Nature 369: 156-160, 1994.

9. Han J, Lee JD, Bibbs L and Ulevitch RJ: A MAP kinase targeted by endotoxin and hyperosmolarity in mammalian cells. Science 265: 808-811, 1994.

10. Engelberg D: Stress-activated protein kinases - tumor suppressors or tumor initiators? Semin Cancer Biol 14: 271-282, 2004

11. Satyamoorthy K, Li G, Gerrero MR, Brose MS, Volpe P, Weber BL, Van Belle P, Elder DE and Herlyn M: Constitutive mitogenactivated protein kinase activation in melanoma is mediated by both BRAF mutations and autocrine growth factor stimulation. Cancer Res 63: 756-759, 2003.

12. Allen LF, Sebolt-Leopold J and Meyer MB: CI-1040 (PD184352), a targeted signal transduction inhibitor of MEK (MAPKK). Semin Oncol 30: 105-116, 2003.

13. Hood JD and Cheresh DA: Role of integrins in cell invasion and migration. Nat Rev Cancer 2: 91-100, 2002.

14. Frisch SM, Vuori K, Ruoslahti E and Chan-Hui PY: Control of adhesion-dependent cell survival by focal adhesion kinase. J Cell Biol 134: 793-799, 1996.

15. Sieg DJ, Hauck CR, Ilic D, Klingbeil CK, Schaefer E, Damsky CH and Schaepfer DD: FAK integrates growth factor and integrin signals to promote cell migration. Nature Cell Biol 2: 249-256, 2000 .

16. Owens LV, Xu L, Craven RJ, Dent GA, Weiner TM, Kornberg L, Liu ET and Cange WG: Overexpression of the focal adhesion kinase (p125FAK) in invasive human tumor. Cancer Res 55: 2752-2755, 1995.
17. Kahana O, Micksche M, Witz IP and Yron I: The focal adhesion kinase (P125FAK) is constitutively active in human malignant melanoma. Oncogene 21: 3969-3977, 2002.

18. Price JT and Thompson EW: Mechanisms of tumour invasion and metastasis: emerging targets for therapy. Expert Opin Ther Targets 6: 217-233, 2002 .

19. Tsuji T, Kawada Y, Kai-Murozono M, Komatsu S, Han SA, Takeuchi K, Mizushima H, Miyazaki K and Irimura T: Regulation of melanoma cell migration and invasion by laminin-5 and alpha3beta1 integrin (VLA-3). Clin Exp Metastasis 19: 127-134, 2002.

20. Giard DJ, Aaronson SA, Todaro GJ, Arnstein P, Kersey JH, Dosik H and Parks WP: In vitro cultivation of human tumors: establishment of cell lines derived from a series of solid tumors. J Natl Cancer Inst 51: 1417-1423, 1973.

21. Gervais FG, Thornberry NA, Ruffolo SC, Nicholson DW and Roy S: Caspases cleave focal adhesion kinase during apoptosis to generate a FRNK-like polypeptitde. J Biol Chem 273: 17102-17108, 1998.

22. Ries LA, Wingo PA, Miller DS, Howe HL, Weir HK, Rosenberg HM, Vernon SW, Cronin K and Edwards BK: The annual report to the nation on the status of cancer, 1973-1997, with a special section on colorectal cancer. Cancer 88: 23982424, 2000.

23. Li G, Satyamoorthy K and Herlyn M: Dynamics of cell interactions and communications during melanoma development. Crit Rev Oral Biol Med 13: 62-70, 2002 .

24. Xia M, Wang M, Tashiro S, Onodera S, Minami M and Ikejima T: Dracorhodin perchlorate induces A375-S2 cell apoptosis via accumulation of p53 and activation of caspases. Biol Pharm Bull 28: 226-232, 2005.

25. Mansouri A, Ridgway LD, Koarapati AL, Zhang Q, Tian L, Wang Y, Siddik ZH, Millis GB and Claret FX: Sustained activation of JNK/p38 MAPK pathways in response to cisplatin leads to Fas ligand induction and cell death in ovarian carcinoma cells. J Biol Chem 278: 19245-19256, 2003.

26. Cuadrado A, Garcia-Fernandez LF, Gonzales L, Suarez Y, Losada A, Alcaide V, Martinez T, Fernandez-Sousa JM, Sanchez-Puelles JM and Munoz A: Aplidin induces apoptosis in human cancer cells via glutathione depletion and sustained activation of the epidermal growth factor receptor, Src, JNK, and p38 MAPK. J Biol Chem 278: 241-250, 2003.

27. Pearson G, Robinson F, Beers Gibson T, Xu BE, Karandikar M, Berman $\mathrm{K}$ and Cobb MH: Mitogen-activated protein (MAP) kinase pathways: regulation and physiological functions. Endocr Rev 22: 153-183, 2001.

28. Kyriakis JM and Avruch J: Mammalian mitogen-activated protein kinase signal transduction pathways activated by stress and inflammation. Physiol Rev 81: 807-869, 2001.

29. Xu L-H, Owens LV, Sturge GC, Yang X, Liu ET, Craven RJ and Cance WG: Attenuation of the expression of the focal adhesion kinase induces apoptosis in tumor cells. Cell Growth Differ 7: 413-418, 1996

30. Hungerford JE, Compton MT, Matter ML, Hoffstrom BG and Otey CA: Inhibition of pp $125 \mathrm{FAK}$ in cultured fibroblasts results in apoptosis. J Cell Biol 135: 1383-1390, 1996.

31. Rimm DL, Caca K, Hu G, Harrison FB and Fearon ER: Frequent nuclear/cytoplasmic localization of beta-catenin without exon 3 mutations in malignant melanoma. Am J Pathol 154: 325-329, 1999.

32. Rubinfeld B, Robbins P, El-Gamil M, Albert I, Porfiri E and Polakis P: Stabilization of beta-catenin by genetic defects in melanoma cell lines. Science 275: 1790-1792, 1997.

33. Cadigan KM and Nusse R: Wnt signalling: a common theme in animal development. Genes Dev 11: 3286-3305, 1997.

34. Maretto S, Cordenonsi M, Dupont S, Braghetta P, Broccoli V, Hassan AB, Volpin D, Bressan GM and Piccolo S: Mapping $\mathrm{Wnt} / \mathrm{B}$-catenin signaling during mouse development and in colorectal tumors. Proc Natl Acad Sci USA 100: 3299-3304, 2003.

35. Murakami T, Toda S, Fujimoto M, Ohtsuki M, Byers HR, Etoh T and Nakagawa $\mathrm{H}$ : Constitutive activation of Wnt/beta-catenin signaling pathway in migration-active melanoma cells: role of LEF-1 in melanoma with increased metastatic potential. Biochem Biophys Res Commun 288: 8-15, 2001. 